\title{
Hematopoietic stem cell transplantations for primary immune deficiencies associated with NFKB mutations: a review of the literature
}

\author{
Ori Scott ${ }^{\mathrm{a}}$ and Eyal Grunebaum ${ }^{\mathrm{a}, \mathrm{b} *}$
}

\begin{abstract}
The nuclear factor kappa-light-chain-enhancer of activated B-cells $(N F K B)$ family of transcription factors plays an instrumental role in human immunity and lymphoid organ development. Inherited defects affecting these factors or their regulation are associated with increased susceptibility to infections, as well as non-immune abnormalities. Hematopoietic stem cell transplantations (HSCT) have been shown to correct the immune abnormalities in a few patients with NFKB pathway defects. Here we review the pre-HSCT characteristics, as well as the HSCT and outcome of 35 patients who received HSCT for NFKB defects. Twenty-three patients (65.7\%) were reported to have survived HSCT. Survival was higher among patients with X-linked ectodermal dysplasia and immunodeficiency (XL-EDA-ID), and those with CARD11-BCL10-MALT1 (CBM) complex defects, in comparison to patients with autosomal dominant ectodermal dysplasia and immunodeficiency (AD-EDA-ID) and IKBKB defects. Survival following myeloablative conditioning was similar to that after reduced intensity conditioning, although donor cells engraftment and immune reconstitution after HSCT was not complete in some patients. The effects of HSCT on organ dysfunction associated with NFkB defects, such as liver toxicity or bowel inflammation, are still not clear. Earlier identification and transplantation of affected patients, as well as better understanding of the pathogenesis and complications of the different $\mathrm{NFKB}$ mutations, might improve outcome of HSCT for specific patient populations.
\end{abstract}

Statement of novelty: This review highlights the current indications, regimens, and outcome of HSCT for inherited defects involving various components of the canonical and non-canonical NFkB pathways.

\section{Introduction}

The nuclear factor kappa-light-chain-enhancer of activated B-cells (NFKB) family of transcription factors plays an instrumental role in human immunity and lymphoid organ development. It comprises of 5 structurally related proteins: NFKB1 (p50), NFKB2 (p52), RelA (p65), RelB, and c-Rel, which bind one another to form hetero- and homo-dimers (Gilmore 2006). In resting cells, the dimers are bound by Inhibitors of NFкB (IкB), which maintain them inactively sequestered in the cell cytoplasm. The precursors of p50 and p52: p100 and p105, respectively, also have the capacity to bind NFKB dimers in an inhibitory manner while in the cytoplasm. In response to various stimuli, NFKB inhibitors undergo phosphorylation by the I $\mathrm{K}$ kinase complex (IKK). This results in the release of NFKB dimers and their migration to the nucleus (Courtois 2005; Gilmore 2006).

The process of NFKB activation occurs by 1 of 2 cascades, known as the canonical and non-canonical pathways (Figure 1). The canonical pathway is induced in response to ligation of a wide array of receptors,
aDivision of Immunology and Allergy, Department of Paediatrics, The Hospital for Sick Children, University of Toronto, Toronto, ON; ' ${ }^{b}$ Developmental and Stem Cell Biology, Research Institute, The Hospital for Sick Children, Toronto, ON

*Corresponding author: Eyal Grunebaum/eyal.grunebaum@sickkids.ca
Submitted 24 December 2016

Accepted 12 February 2017

Available online 20 March 2017

LymphoSign Journal 4:45-62 (2017)

dx.doi.org/10.14785/lymphosign-2016-0016 


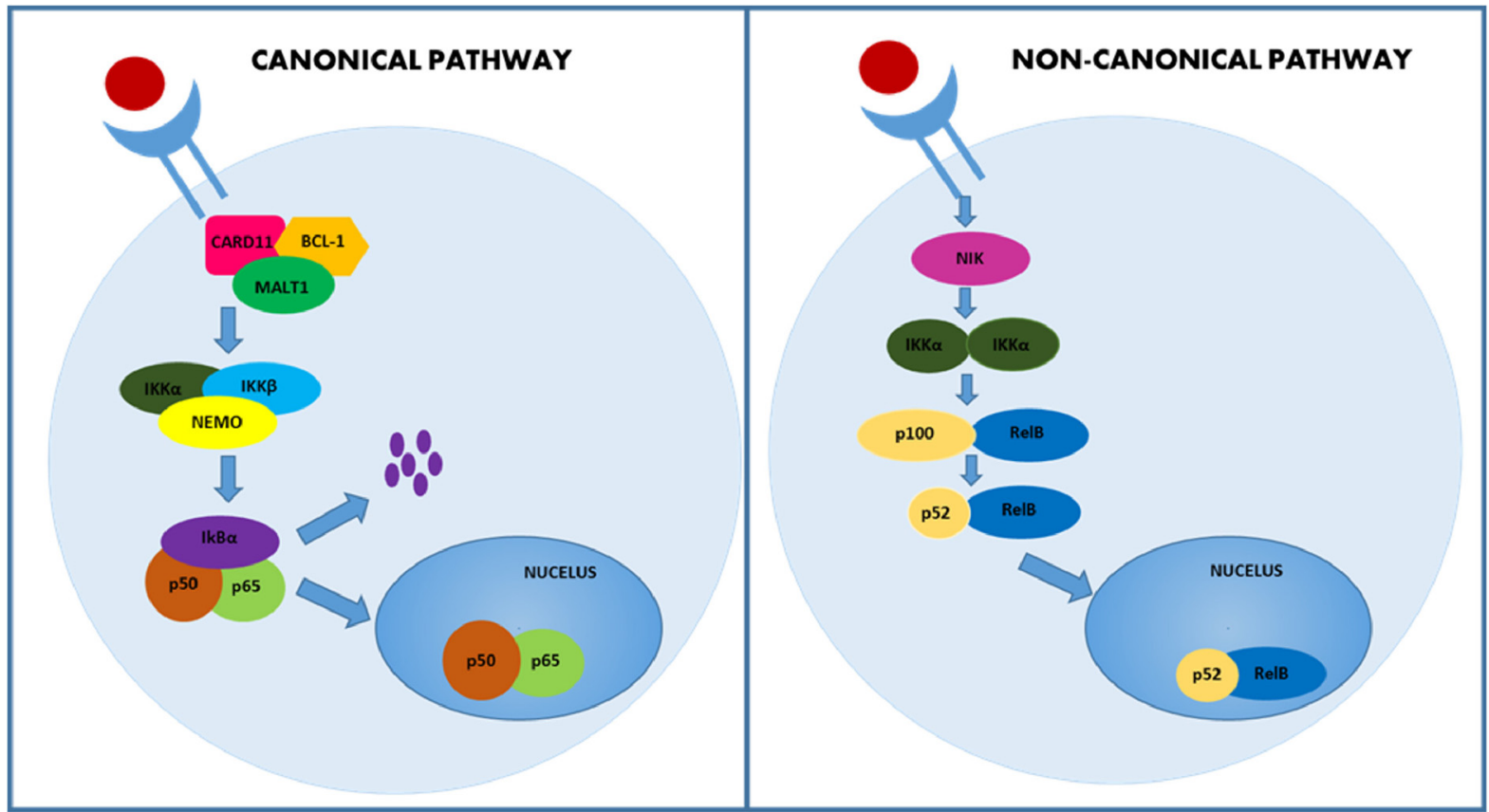

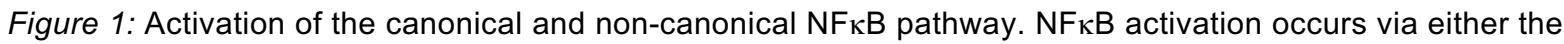
canonical and non-canonical pathways. In the canonical pathway (left), stimulation of TLR, IL-1, or TNF receptor leads to recruitment and activation of the IKK complex, consisting of 2 catalytic units (IKK $\alpha$ and IKK $\beta$ ) and a sensing protein, NFKB essential modulator (NEMO). This is mediated in part by the CARD11-BCL10-MALT1 (CBM) signalosome, which links receptor binding to NFKB activation. IKK phosphorylation of $I_{\kappa} B$ molecules, results in ubiquitination and degradation of $I_{\kappa} B$, thus liberating the $N F \kappa B$ dimer to migrate to the nucleus where it serves as a transcription regulator. In the non-canonical pathway (right), binding of lymphotoxin- $\beta$ receptor, B-cell activating factor receptor, and CD40, activates the NFKB-inducing kinase (NIK). NIK activates a unique IKK complex, made up strictly of IKK $\alpha$ subunits. In turn, IKK phosphorylates $p 100$, which is bound to the NFKB dimer, resulting in proteolysis of $\mathrm{p} 100$ and release of the transcription factor.

including Toll-like receptors (TLR), interleukin (IL)-1, and tumor necrosis factor (TNF) receptor superfamilies. Stimulation of these cell-surface receptors leads to recruitment and activation of the IKK complex, consisting of 2 catalytic units (IKK $\alpha$ and IKK $\beta$ ) and a sensing protein, NFkB essential modulator (NEMO). The process of IKK recruitment is mediated in part by the CARD11BCL10-MALT1 (CBM) signalosome, a complex of 3 proteins, which links receptor binding to NFKB activation. IKK phosphorylation of IкB molecules, most commonly I $\mathrm{B} \alpha$, results in ubiquitination and degradation of I $\mathrm{B}$. Subsequently, the liberated NFKB dimer migrates to the nucleus where it regulates target gene transcription (Smahi et al. 2002; Gilmore 2006).

The non-canonical pathway is most commonly activated during lymphoid organ development. Stimulation of specific receptors, such as lymphotoxin- $\beta$ receptor, B-cell activating factor receptor, and CD40, activates the NFKB-inducing kinase (NIK). NIK activates a unique IKK complex, made up strictly of IKK $\alpha$ subunits. In turn, IKK phosphorylates p100, which is bound to the $\mathrm{NF \kappa B}$ dimer, resulting in proteolysis of p100 and release of the transcription factor (Smahi et al. 2002; Gilmore 2006).

Inherited defects in the NFKB pathway have been described in an increasing number of patients with heterogeneous phenotypes. Infectious susceptibility in patients with NFKB pathway mutations range from mild to severe. These may include recurrent sinopulmonary and gastrointestinal infections with failure to thrive (FTT), bacterial, opportunistic infections or atypical mycobacterial infections, and severe systemic life-threatening infections (Smahi et al. 2002; Courtois 2005). Supportive therapies for patients with NFKB pathway defects include antimicrobial prophylaxis and immunoglobulin replacement. Importantly, because NFKB defects do not prevent thymocyte development and generation of T-cells, newborn screening for severe immunodeficiency using T-cell receptor excision circles will not detect most patients. Hence, most children with 
NFKB defects will often present with infections. Hematopoietic stem cell transplantations (HSCT) have been attempted in some patients with NFkB defects, with most reports describing single patients or very small case-series. Significant variability exists in the literature with respect to indications for HSCT, age at time of HSCT, conditioning regimens and stem cell source. Furthermore, the long-term engraftment, immunologic outcome and clinical benefit of this therapeutic option are largely unknown.

In an attempt to better characterize the role of HSCT for NFkB defects, we review here the data reported in the English literature for 35 patients with various NFKB pathway mutations who received HSCT. Articles were identified via an electronic search of the Medline, Embase, and PASCAL databases, between 1 June and 29 August 2016. Published articles detailing experience with human patients were included. Only English reports were reviewed. Research abstracts and unpublished data were not included. The following search terms were used: nuclear factor kappa-lightchain-enhancer of activated B-cells (NFkB), RelA,

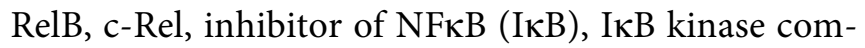
plex (IKK), NEMO, CARD11, BCL10, MALT1, NFKBinducing kinase (NIK), ectodermal dysplasia, and hematopoietic stem cell transplant. MESH headings and keywords were searched and truncation was used as needed.

\section{X-linked ectodermal dysplasia with immunodeficiency}

Hypomorphic mutations in the IKBKG gene, located on the $\mathrm{X}$ chromosome, lead to a partial lossof-function of NEMO (IKK $\gamma$ ), the regulatory subunit of IKK complex in the canonical pathway. The resultant phenotype often includes ectodermal dysplasia (EDA), marked by conical or absent teeth, sparse hair, brittle nails, and hypo- or an-hydrosis due to abnormal or absent sweat glands. Accordingly, the condition is often referred to as X-linked ectodermal dysplasia with immunodeficiency (XL-EDA-ID). Osteopetrosis and lymphedema have also been reported infrequently in affected patients (Orange and Geha 2003). Females carrying heterozygous mutations in $I K B K G$ gene may display incontinentia pigmenti, although different ratios of the wild-type relative to the mutated alleles contributes to phenotype diversity, and a female with EDA and increased susceptibility to infections was previously described (Martinez-Pomar et al. 2005).

Between 2002 and 2016, 13 patients with XL-EDA-ID were reported to have undergone HSCT (Dupuis-Girod et al. 2002; Orange et al. 2004; Tono et al. 2007; Mancini et al. 2008; Pai et al. 2008; Salt et al. 2008; Fish et al. 2009; Minakawa et al. 2009; Permaul et al. 2009; Imamura et al. 2011; Kawai et al. 2012; Abbott et al. 2014; Carlberg et al. 2014; Klemann et al. 2016). A summary of patient characteristics prior to HSCT can be found in Table 1. Patients typically presented early in life (between birth to 9 months of age), with recurrent and (or) opportunistic infections (pneumocystis jiroveci pneumonia (PJP)), cytomegalovirus (CMV), nonTuberculous mycobacteria, and Candida. Severe eczema, chronic diarrhea, feeding intolerance, and (or) FTT, were reported in 10 of the patients. Immunologic evaluation prior to HSCT demonstrated hypogammaglobulinemia in 10 patients. Antibody synthesis, primarily against polysaccharide antigens, were diminished or absent in 6 patients and not reported in 7 others. T-cell proliferation responses to lectin mitogens were overall normal, but whole blood response to TLR, IL-1, and TNF receptor agonists were poor, often with abnormal production of antibodies.

HSCT details and outcome are provided in Table 2. At time of first transplant, patients were between 5 and 65 months of age. Myeloablative conditioning (MAC) was employed in 5 patients, while reduced intensity conditioning (RIC) in 6 patients. Stem cell sources included bone marrow (BM) and mobilized peripheral blood mononuclear cells (PBMC), each in 2 patients, while umbilical cord blood were used for 5 patients. Human leukocyte antigen (HLA) mismatched or matched unrelated donors (MUD) were used in 8 patients, while 5 patients received cells from HLA matched related donors (MRD). Among the MRD was a female donor who was known to carry the mutation and suffered from autoimmune symptoms (Klemann et al. 2016). Successful donor engraftment was reported in 7 patients, 5 following MAC and 2 following RIC. One patient died prior to engraftment. Failure of engraftment was reported in 4 patients, 3 following RIC, while conditioning was not reported for the 4th patient. A 2nd HSCT was performed in 2 of the patients who failed to engraft, while another patient who had poor $\mathrm{T}$ cell engraftment died from septic shock 60 days after HSCT. Death was reported 


\begin{tabular}{|c|c|c|c|c|c|}
\hline Patient \# & Mutation & $\begin{array}{l}\text { Age at } \\
\text { presentation }\end{array}$ & Clinical manifestations and pathogens & Immune abnormalities & Report \\
\hline 1 & c.337G >A & $6 \mathrm{mo}$ & PJP, CMV & $\begin{array}{l}\text { (1) Reduced NK activity; (2) Absent T-cell } \\
\text { responses to antigens; (3) Reduced response } \\
\text { to Streptococcus pneumoniae vaccine }\end{array}$ & $\begin{array}{l}\text { Salt et al. 2008; Abbott } \\
\text { et al. } 2014 \text { Patient } 1\end{array}$ \\
\hline 2 & c. $437 \mathrm{~T}>\mathrm{G}$ & $9 \mathrm{mo}$ & $\begin{array}{l}\text { Severe eczema, chronic diarrhea, vomiting, } \\
\text { FTT, Methicillin-resistant Staphylococcus } \\
\text { aureus (MRSA) abscess, CMV }\end{array}$ & $\begin{array}{l}\text { (1) Leukocytosis with eosinophilia; } \\
\text { (2) Undetectable IgM and IgG }\end{array}$ & $\begin{array}{l}\text { Devora et al. 2010; } \\
\text { Abbott et al. } 2014 \\
\text { Patient } 2\end{array}$ \\
\hline 3 & p.Glu157Pro & $7 d$ & $\begin{array}{l}\text { Lymphedema, osteopetrosis, feeding } \\
\text { intolerance, Gram (-), CMV, PJP, MRSA }\end{array}$ & $\begin{array}{l}\text { (1) Leukocytosis; (2) Absent T- and B-cell } \\
\text { clones; (3) Hypogam }\end{array}$ & Carlberg et al. 2014 \\
\hline 4 & X420W & Birth & $\begin{array}{l}\text { Chronic diarrhea, feeding intolerance, FTT, } \\
\text { lymphedema, osteopetrosis, Gram (+) and } \\
(-), \text { PJP, Candida, Mycobacterium kanasii }\end{array}$ & $\begin{array}{l}\text { (1) Leukocytosis; (2) Hypogam; (3) Reduced } \\
\text { response to S. pneumoniae vaccine; } \\
\text { (4) Reduced responses to TLR, TNF stimulation }\end{array}$ & Dupuis-Girod et al. 2002 \\
\hline 5 & $\begin{array}{c}\text { 1167-1168insC } \\
\text { (E390fsX394) }\end{array}$ & NA & $\begin{array}{l}\text { Recurrent fevers, diarrhea, FTT, } \\
\text { desquamating erythema }\end{array}$ & (1) Hypogam & Fish et al. 2009 Patient 1 \\
\hline 6 & IVS6+5 G $\rightarrow A$ & 5 wk & $\begin{array}{l}\text { Vomiting, diarrhea, FTT, lymphedema, } \\
\text { osteopetrosis, cerebral venous sinus } \\
\text { thrombosis, bacterial, Clostridium difficile } \\
\text { colitis; varicella zoster virus, Mycobacterium } \\
\text { avium }\end{array}$ & $\begin{array}{l}\text { (1) Increased naïve B-cells; (2) Hypogam, } \\
\text { high IgM; (3) Reduced responses to } \\
\text { Streptococcus vaccines including } \\
\text { S. pneumoniae; (4) Reduced responses to } \\
\text { TLR, TNF }\end{array}$ & Fish et al. 2009 Patient 2 \\
\hline 7 & D311E & $30 \mathrm{mo}$ & Disseminated BCG & $\begin{array}{l}\text { (1) Reduced NK activity; (2) Absent antibody } \\
\text { response to vaccines; (3) Reduced response } \\
\text { to TLR }\end{array}$ & Imamura et al. 2011 \\
\hline 8 & $\begin{array}{l}\text { Duplication intron } \\
3 \text { to exon } 6\end{array}$ & Infancy & FTT, Mycobacteria & $\begin{array}{l}\text { (1) Low NK cells; (2) Low TCR } \gamma / \delta \text {; } \\
\text { (3) Hypogam, low IgM; (4) Reduced T-cell } \\
\text { responses to mitogens }\end{array}$ & Kawai et al. 2012 \\
\hline 9 & c. $613 \mathrm{C}>\mathrm{T}$ & 3 wk & $\begin{array}{l}\text { Staphylococcus, necrotizing fasciitis, } \\
\text { pneumonia, Enterobacter cloacae, meningitis }\end{array}$ & (1) Reduced NK activity & Klemann et al. 2016 \\
\hline 10 & $\begin{array}{l}\text { 1167-1168insC } \\
\text { (E390fsX394) }\end{array}$ & 12 wk & $\begin{array}{l}\text { FTT, diarrhea, feeding intolerance, skin } \\
\text { infections }\end{array}$ & $\begin{array}{l}\text { (1) Leukocytosis with lymphocytosis and } \\
\text { eosinophilia; (2) Increased total T-cell count; } \\
\text { (3) Decreased NK count; (4) Hypogam and } \\
\text { low IgM, absent IgA; (5) Reduced antibody } \\
\text { response to vaccines }\end{array}$ & Mancini et al. 2008 \\
\hline 11 & T458G & NA & FTT, CMV, bacteremias, Listeria & $\begin{array}{l}\text { (1) Leukocytosis; (2) Reduced NK activity; } \\
\text { (3) Hypogam; (4) Reduced antibody response } \\
\text { to vaccines; (5) Reduced B-cell proliferation; } \\
\text { (6) Diminished responses to TLR }\end{array}$ & $\begin{array}{l}\text { Orange et al. } 2004 \\
\text { Pai et al. } 2008\end{array}$ \\
\hline 12 & $\begin{array}{l}\text { 1167-1168insC } \\
\text { (E390fsX394) }\end{array}$ & 6 wk & $\begin{array}{l}\text { Severe dermatitis, chronic diarrhea, feeding } \\
\text { intolerance, FTT, osteopetrosis, bacterial } \\
\text { infections }\end{array}$ & $\begin{array}{l}\text { (1) Leukocytosis with eosinophilia; (2) Elevated } \\
\text { T and B cell; (3) Hypogam; (4) Reduced NK } \\
\text { activity }\end{array}$ & Permaul et al. 2009 \\
\hline 13 & $\begin{array}{c}\text { 1167-1168insC } \\
\text { (E390fsX394) }\end{array}$ & $2 \mathrm{mo}$ & $\begin{array}{l}\text { Enterocolitis, feeding intolerance, gastric } \\
\text { ulcers, severe eczema, Gram (-) }\end{array}$ & $\begin{array}{l}\text { (1) Elevated B-cells; (2) Hypogam; (3) Reduced } \\
\text { NK activity }\end{array}$ & $\begin{array}{l}\text { Tono et al. 2007; } \\
\text { Minakawa et al. } 2009\end{array}$ \\
\hline
\end{tabular}

Note: HSCT, hematopoietic stem cell transplantation; NA, not available; MAC, myeloablative conditioning; RIC, reduced intensity conditioning; Bu, busulfan; Cy, cyclophosphamide; Flu, fludarabine; Mel, melphalan; ATG, antithymocyte globulin; Alem, alemtuzumab; CB, cord blood; BM, bone marrow; PBSC, peripheral blood stem cells; MSD, matched sibling donor; MUD, matched unrelated donor; MMUD, mismatched unrelated donor; AGvHD, acute graft versus host disease; FTT, failure to thrive; Hypogam, hypogammaglobulinemia. 
Table 2: Outcome of patients after transplantation for X-linked ectodermal dysplasia with immunodeficiency.

\begin{tabular}{|c|c|c|c|c|c|c|}
\hline Patient \# & $\begin{array}{l}\text { Age at } \\
\text { HSCT }\end{array}$ & $\begin{array}{l}\text { Conditioning, } \mathrm{HLA} \text {, } \\
\text { cell source }\end{array}$ & $\begin{array}{l}\text { Follow up } \\
\text { post-HSCT }\end{array}$ & $\begin{array}{l}\text { Evaluation post-HSCT } \\
\text { (time post-HSCT) }\end{array}$ & Outcome & Report \\
\hline 1 & $2 \mathrm{yr}$ & $\begin{array}{l}\text { MAC (Bu/Cy/ATG), } \\
\text { MUD, CB }\end{array}$ & $6 \mathrm{yr}$ & $\begin{array}{l}\text { (1) Complete donor chimerism (NA); (2) } \\
\text { Complete B-and T-cell reconstitution } \\
\text { (NA); (3) Normal response to vaccines }\end{array}$ & $\begin{array}{l}\text { (1) Clinically well; (2) Allergy to sulfa } \\
\text { and walnuts }\end{array}$ & $\begin{array}{l}\text { Salt et al. 2008; Abbott } \\
\text { et al. } 2014 \text { Patient } 1\end{array}$ \\
\hline 2 & $2 \mathrm{yr}$ & $\begin{array}{l}\text { MAC (Bu/Cy/ATG), } \\
\text { MUD, CB }\end{array}$ & $6 \mathrm{yr}$ & $\begin{array}{l}\text { (1) Complete donor chimerism (NA); (2) } \\
\text { Complete B-and T-cell reconstitution } \\
\text { (NA); (3) Normal response to vaccines }\end{array}$ & Clinically well & $\begin{array}{l}\text { Salt et al. 2008; Abbott } \\
\text { et al. } 2014 \text { Patient } 2\end{array}$ \\
\hline 3 & $5 \mathrm{mo}$ & NA, MSD, NA & $10 \mathrm{mo}$ & NA & $\begin{array}{l}\text { (1) Skin abnormalities persist; } \\
\text { (2) Improved weight }\end{array}$ & Carlberg et al. 2014 \\
\hline 4 & $17 \mathrm{mo}$ & $\begin{array}{l}\text { MAC (Bu/Cy/ATG), } \\
\text { MUD, NA }\end{array}$ & $11 \mathrm{~d}$ & NA & $\begin{array}{l}\text { (1) Died; (2) Cardiovascular, skin and } \\
\text { liver toxicity, seizures }\end{array}$ & Dupuis-Girod et al. 2002 \\
\hline \multirow[t]{2}{*}{5} & $6 \mathrm{mo}$ & $\begin{array}{l}\text { RIC (Flu/Bu/ATG) } \\
\text { MSD, PSC }\end{array}$ & & (1) Failed to engraft & Colitis & $\begin{array}{l}\text { Fish et al. } 2009 \text { Patient } 1 \\
\text { 1st HSCT }\end{array}$ \\
\hline & NA & $\begin{array}{l}\text { RIC (Flu/Mel/Alem), } \\
\text { MSD, PBSC }\end{array}$ & & (2) $98 \%$ T-cell chimerism & $\begin{array}{l}\text { (1) Appropriate development. } \\
\text { (2) Persistent abnormal dentition, } \\
\text { rashes, diarrhea, FTT }\end{array}$ & 2nd HSCT \\
\hline \multirow[t]{2}{*}{6} & $41 \mathrm{mo}$ & $\begin{array}{l}\text { RIC (Flu/Bu/ATG), } \\
\text { MUD, BM }\end{array}$ & NA & (1) Failed to engraft & $\begin{array}{l}\text { (1) Intracranial hemorrhage leading to a } \\
\text { seizure; (2) Multi-organism infection }\end{array}$ & $\begin{array}{l}\text { Fish et al. } 2009 \text { Patient } 2 \\
\text { 1st HSCT }\end{array}$ \\
\hline & $43 \mathrm{mo}$ & $\begin{array}{l}\text { RIC (Flu), MUD, } \\
\text { CD34+ PBSC }\end{array}$ & $314 \mathrm{~d}$ & (2) $100 \%$ Donor chimerism (16 d) & $\begin{array}{l}\text { (1) Died. (2) FTT, Parainfluenza leading } \\
\text { to respiratory failure }\end{array}$ & 2nd HSCT \\
\hline 7 & $4.9 \mathrm{yr}$ & $\begin{array}{l}\text { RIC (Flu/Mel/ATG), } \\
\text { MUD, BM }\end{array}$ & $20 \mathrm{mo}$ & Complete donor chimerism (NA) & $\begin{array}{l}\text { (1) Clinically well; (2) AGvHD } \\
\text { (resolved); (3) CMV; (4) Multiple } \\
\text { papillomas }\end{array}$ & Imamura et al. 2011 \\
\hline 8 & $26 \mathrm{mo}$ & $\begin{array}{l}\text { RIC (Flu/Mel/ATG), } \\
\text { MMUD, CB }\end{array}$ & $60 \mathrm{~d}$ & $\begin{array}{l}\text { (1) No T-cell chimerism; (2) "Good" B, } \\
\text { NK cells, and monocytes chimerism }\end{array}$ & $\begin{array}{l}\text { (1) Died from septic shock. } \\
\text { (2) Tacrolimus-induced } \\
\text { encephalopathy }\end{array}$ & Kawai et al. 2012 \\
\hline 9 & $11 \mathrm{mo}$ & $\begin{array}{l}\text { MAC (Bu/Cy/ATG), } \\
\text { MSD, NA }\end{array}$ & $8 \mathrm{yr}$ & $\begin{array}{l}\text { (1) Full chimerism and immune } \\
\text { reconstitution (NA); (2) Normal NK } \\
\text { function }\end{array}$ & $\begin{array}{l}\text { (1) Severe veno-occlusive disease; } \\
\text { (2) Severe inflammatory bowel } \\
\text { disease }\end{array}$ & Klemann et al. 2016 \\
\hline 11 & NA & NA, MSD, PBSC & NA & Declining chimerism & (1) AGvHD; (2) Psuedotumor cerebri & Mancini et al. 2008 \\
\hline 12 & $65 \mathrm{mo}$ & $\begin{array}{l}\text { MAC (Bu/Cy), MSD, } \\
\text { NA }\end{array}$ & $15 \mathrm{mo}$ & $\begin{array}{l}\text { (1) Lymphoid subset reconstitution; (2) } \\
\text { Normal T-cell responses; (3) Improved } \\
\text { B, NK, and monocyte responses; (4) } \\
98 \%-100 \% \text { chimerism in leukocyte } \\
\text { and lymphocytes subsets (8-19 mo) }\end{array}$ & $\begin{array}{l}\text { (1) CMV reactivation; (2) Recurrent } \\
\text { bacterial infections of respiratory tract, } \\
\text { skin, and gastrointestinal tract; } \\
\text { (3) colitis }\end{array}$ & $\begin{array}{l}\text { Orange et al. } 2004 \\
\text { Pai et al. } 2008\end{array}$ \\
\hline 13 & $7.5 \mathrm{mo}$ & $\begin{array}{l}\text { MAC (Bu/Cy/ATG), } \\
\text { MMUD, CB }\end{array}$ & $18 \mathrm{mo}$ & $\begin{array}{l}\text { (1) Lymphocyte counts, NK function, } \\
\text { and IgG normalized (1 yr); (2) 99\%- } \\
100 \% \text { chimerism all lineages (1 yr) }\end{array}$ & $\begin{array}{l}\text { (1) Clinically well; (2) Infections, } \\
\text { gastrointestinal symptoms, } \\
\text { osteopetrosis, and dermatitis resolved }\end{array}$ & Permaul et al. 2009 \\
\hline 14 & $3 y r$ & $\begin{array}{l}\text { RIC (Flu/Mel/ATG), } \\
\text { MMUD, CB }\end{array}$ & $12 \mathrm{mo}$ & $\begin{array}{l}\text { (1) Improved TLR responses; (2) } \\
\text { Complete leukocyte chimerism (105 d) }\end{array}$ & (1) Clinically well; (2) AGvHD (resolved) & $\begin{array}{l}\text { Tono et al. 2007; } \\
\text { Minakawa et al. } 2009\end{array}$ \\
\hline
\end{tabular}

Note: NA, not available; FTT, failure to thrive, Hypogam- hypogammaglobulinemia. 
in 2 additional patients, including a patient who died 1 year after a 2 nd HSCT from respiratory failure following a viral infection, and a patient that died 11 days after MAC conditioning from severe hepatic toxicity. Indeed, it has been hypothesized that the increased susceptibility to hepatic injury and veno-occlusive disease after transplantation for NEMO correlates with the in vitro sensitivity of cells with inhibited NFKB activity due to chemotherapy-induced apoptosis (Klemann et al. 2016). Clinical outcome was variable among children who engrafted successfully. Among the 7 patients who were reported to be 12 months or more post-HSCT, 5 are reported to be clinically well, while 2 developed persistent gastrointestinal complications after HSCT. Some of the gastrointestinal complications following HSCT in NEMO-deficient hosts have been attributed to the introduction of a competent immune system, which allows increased translocation of enteric bacteria, leading to a severe chronic intestinal infection and inflammation (Nenci et al. 2007). However, it is difficult to distinguish a propensity of patients with NEMO to develop GI complications following HSCT from pretransplant GI complications, which are common in these patients, or from graft versus host disease. Regardless of the cause, the GI complications might have further contributed to the chronic diarrhea, feeding intolerance and (or) poor growth reported in 5 patients following HSCT. Immune evaluations done 2 years or more after HSCT demonstrated that those who received MAC from healthy donors had complete $\mathrm{T}$ and $\mathrm{B}$ cell reconstitution, with adequate response to conjugate and live virus vaccines (Abbott et al. 2014). Altogether, the patients described above indicate that HSCT can correct the immune deficiency associated with NEMO deficiency, particularly if MAC is used and full donor chimerism is achieved. However, the potential liver toxicity and persistence of the defect in non-hematopoietic cells, including the GI tract, may adversely affect long-term clinical benefits from HSCT in patients with NEMO defects. Whether RIC can achieve long-term immune reconstitution in patients with NEMO still needs to be determined.

\section{Autosomal dominant ectodermal dysplasia with immunodeficiency}

Heterozygous gain-of-function mutations in the NFKBIA gene enhance the activity of the inhibitory protein $\mathrm{IkB} \alpha$, thus limiting the release of $\mathrm{NF \kappa B}$ dimers via the canonical pathway. Similarly to XL-EDA-ID, autosomal dominant mutations in NFKBIA result in a phenotype of EDA, often associated with more profound immunodeficiency, termed autosomal dominant ectodermal dysplasia with immunodeficiency (AD-EDA-ID).

Between the years 2003 and 2015, reports of 7 patients with AD-EDA-ID who underwent HSCT were published (Courtois et al. 2003; Janssen et al. 2004; Dupuis-Girod et al. 2006; Lopez-Granados et al. 2008; Fish et al. 2009; Wu et al. 2010; Schimke et al. 2013; Yoshioka et al. 2013; Scarselli et al. 2015). A summary of patient characteristics can be found in Table 3 . Patients presented in the first 6 months of life with chronic diarrhea, feeding intolerance and FTT. Infections described in these patients included recurrent invasive bacterial infections, PJP, and candidiasis. One infant also suffered from hypothalamic hypopituitarism and another had developmental delay. The pre-transplant immunologic assessment revealed predominance of naïve CD45RA T-helper cells with lack of CD45RO memory cells in 2 patients, with reduced or absent TCR $\gamma / \delta$ T-cells in 3 patients. T-cell responses to CD3 stimulation were diminished in 5 patients. B-cell counts were low in 2 patients, with decreased memory B-cells and impaired B-cell response to CD40 stimulation. Hypogammaglobulinemia was seen in 3 patients, with poor antibody formation to both polysaccharide and protein antigens. Whole blood responses to TLR, IL-1, and TNF agonists were impaired in 5 children.

HSCT were performed at 10 months to 6 years of age (Table 4). Mis-MUD and MUD were used for 5 patients while mis-MRD and MRD were used for 2 patients. MAC and RIC were each used for 3 patients, while for 1 patient conditioning was not reported. A patient who received RIC failed to engraft and was re-transplanted following MAC, however the patient died shortly after transplant from bacterial sepsis. Four additional patients died from bacterial infections or neurological deterioration, thus only 2 patients are long-term survivors, both after MAC. Disappointingly these patients continue to suffer from diverse complications, which might be in part related to incomplete immune reconstitution and (or) the nonimmune abnormalities associated with NFkB deficiency. Hence, the role of HSCT for AD-EDA-ID is still not clear.

\section{IKK2 immunodeficiency}

Autosomal dominant loss-of-function mutations in the $I K B K B$ gene disrupt the activation of the canonical 
Table 3: Characteristics of patients prior to transplantation for autosomal dominant ectodermal dysplasia with immunodeficiency.

\begin{tabular}{|c|c|c|c|c|c|}
\hline Patient \# & Mutation & $\begin{array}{c}\text { Age at } \\
\text { presentation }\end{array}$ & Clinical manifestations and pathogens & Immune abnormalities & Report \\
\hline 1 & S321 & $2 \mathrm{mo}$ & $\begin{array}{l}\text { Chronic diarrhea, hepatosplenomegaly, } \\
\text { FTT, Gram (+) and (-); pneumonia, } \\
\text { Candidiasis }\end{array}$ & $\begin{array}{l}\text { (1) Leukocytosis, neutrophilia, and lymphocytosis; } \\
\text { (2) Increased CD45RA T-cells; (3) Absent TCR } \gamma / \delta \text {; } \\
\text { (4) Hypogam, low IgA; (5) Absent responses to } \\
\text { vaccines; (6) Reduced/absent T-cell responses; } \\
\text { (7) Reduced responses to TLR, TNF- } \alpha\end{array}$ & $\begin{array}{l}\text { Courtois et al. 2003; } \\
\text { Dupuis-Girod et al. } \\
2006\end{array}$ \\
\hline 2 & $\begin{array}{l}\text { STOP codon at } \\
\text { Glu14 }\end{array}$ & Birth & $\begin{array}{l}\text { Chronic diarrhea, FTT, recurrent bacterial } \\
\text { sepsis, PJP }\end{array}$ & NA & Fish et al. 2009 \\
\hline 3 & c. $40 G>T$ & $2 \mathrm{mo}$ & $\begin{array}{l}\text { Feeding intolerance, diarrhea, failure to } \\
\text { thrive PJP pneumonia, recurrent } \\
\text { pyogenic bacterial, oral Candidiasis }\end{array}$ & $\begin{array}{l}\text { (1) Reduced TCR } \gamma / \delta \text { counts; } \\
\text { (2) Reduced T cell responses; } \\
\text { (3) Reduced response to TLR }\end{array}$ & $\begin{array}{l}\text { Lopez-Granados } \\
\text { et al. } 2008\end{array}$ \\
\hline 4 & NA & NA & NA & Low B-cells & Scarselli et al. 2015 \\
\hline 5 & M37K & $6 \mathrm{mo}$ & $\begin{array}{l}\text { Hypothyroidism, hypothalamic } \\
\text { hypopituitarism, diarrhea, failure to thrive, } \\
\text { recurrent candidiasis, recurrent sino- } \\
\text { pulmonary infections }\end{array}$ & $\begin{array}{l}\text { (1) Leukocytosis with lymphocytosis; (2) Decreased } \\
\text { memory B-cells; (3) Increased CD4 and low CD8; } \\
\text { (4) Increased CD45RA; (5) Hypogam and low IgA, } \\
\text { high IgM; (6) No response to vaccines; (7) Reduced } \\
\text { T-cell responses; (8) Reduced response to TLR, } \\
\text { TNF- } \alpha\end{array}$ & Schimke et al. 2013 \\
\hline 6 & c. $107 \mathrm{C}>\mathrm{A}$ & $4 \mathrm{mo}$ & $\begin{array}{l}\text { Gastrointestinal inflammation, recurrent } \\
\text { bacterial infection, BCG skin abscess }\end{array}$ & $\begin{array}{l}\text { (1) Leukocytosis with lymphopenia and neutrophilia; } \\
\text { (2) Decreased B-cell response; (3) Decreased } \\
\text { memory CD8 cells; (4) Elevated IgG, IgA; } \\
\text { (5) Reduced T-cell proliferation; (6) Reduced } \\
\text { responses to TLR, TNF- } \alpha\end{array}$ & Yoshioka et al. 2013 \\
\hline 7 & NA & $2 \mathrm{mo}$ & $\begin{array}{l}\text { Diarrhea, FTT, delayed development, } \\
\text { Streptococcal sepsis and meningitis, } \\
\text { PJP, candidiasis }\end{array}$ & $\begin{array}{l}\text { (1) Leukocytosis and lymphocytosis; (2) Low B-cell } \\
\text { and NK count, high CD4; (3) Absent TCR } \gamma / \delta \text { cells; } \\
\text { (4) Low IgG, IgA, high IgM; (5) No response to } \\
\text { vaccines; (6) Reduced T-cell responses; (7) Absent } \\
\text { response to TLR, IFN- } \gamma\end{array}$ & $\begin{array}{l}\text { Janssen et al. } 2004 \text {; } \\
\text { Wu et al. } 2010\end{array}$ \\
\hline
\end{tabular}

Note: NA, not available; FTT, failure to thrive; Hypogam, hypogammaglobulinemia. 
Table 4: Outcome of patients after transplantation for autosomal dominant ectodermal dysplasia with immunodeficiency.

\begin{tabular}{|c|c|c|c|c|c|c|}
\hline Patient \# & $\begin{array}{l}\text { Age at } \\
\mathrm{HSCT}\end{array}$ & $\begin{array}{l}\text { Conditioning, HLA, cell } \\
\text { source }\end{array}$ & $\begin{array}{l}\text { Follow up } \\
\text { post-HSCT }\end{array}$ & Evaluation post-HSCT (time post-HSCT) & Outcome & Report \\
\hline 1 & $12 \mathrm{mo}$ & $\begin{array}{l}\text { MAC (Bu/Cy), MMRD, } \\
\text { BM }\end{array}$ & $7 \mathrm{yr}$ & $\begin{array}{l}\text { (1) T-cell responses (210 d); (2) CD45RO } \\
\text { T-cells (145 d); (3) Response to TLR TNF } \\
\text { normalized; (4) 100\% T-, B-cells, and } \\
\text { monocytes chimerism (7 yr); (5) IgG } \\
\text { and responses to vaccines (except } \\
\text { S. pneumonia) normal; (6) IVIg resumed }\end{array}$ & $\begin{array}{l}\text { (1) Improved height and weight (6 yr); } \\
\text { (2) Recurrent zoster, facial warts, } \\
\text { respiratory tract infections; } \\
\text { (3) Ectodermal dysplasia features not } \\
\text { prevented }\end{array}$ & $\begin{array}{l}\text { Courtois et al. } \\
\text { 2003; Dupuis- } \\
\text { Girod et al. } \\
2006\end{array}$ \\
\hline \multirow[t]{2}{*}{2} & $10 \mathrm{mo}$ & $\begin{array}{l}\text { RIC (Flu/Cy/ATG), } \\
\text { MMUD, CB }\end{array}$ & NA & No engraftment & NA & $\begin{array}{l}\text { Fish et al. } 2009 \\
\text { 1st HSCT }\end{array}$ \\
\hline & $13 \mathrm{mo}$ & $\begin{array}{l}\text { MAC (Bu/Cy/Alem), } \\
\text { MMUD, CB }\end{array}$ & $5 d$ & NA & Died, Pseudomonas sepsis & 2nd HSCT \\
\hline 3 & NA & $\begin{array}{l}\text { MAC (Bu/Cy), MUD, } \\
\text { CB }\end{array}$ & NA & NA & Died, sepsis & $\begin{array}{l}\text { Lopez-Granados } \\
\text { et al. } 2008\end{array}$ \\
\hline 4 & $12 \mathrm{mo}$ & $\begin{array}{l}\text { MAC (Bu/Cy), MMRD, } \\
\text { CD34+ BM }\end{array}$ & $15 \mathrm{yr}$ & $\begin{array}{l}\text { (1) } 95 \% \text { chimerism; (2) Switched and } \\
\text { Memory B-cells absent; (3) IVIg continued }\end{array}$ & $\begin{array}{l}\text { Seizures, PJP pneumonia, chronic } \\
\text { broncho-pneumopathy }\end{array}$ & $\begin{array}{l}\text { Scarselli et al. } \\
2015\end{array}$ \\
\hline 5 & $57 \mathrm{mo}$ & $\begin{array}{l}\text { RIC (Treo/Flu/Alem), } \\
\text { MUD, NA }\end{array}$ & $18 \mathrm{mo}$ & $\begin{array}{l}\text { (1) } 80 \%-90 \% \text { (15 mo); (2) Normal T, B, } \\
\text { NK cells; (3) Absent switched memory } \\
\text { B-cells; (4) T cell responses normalized } \\
\text { (1 yr); (5) IVlg continued }\end{array}$ & $\begin{array}{l}\text { (1) AGvHD and CGvHD; (2) Died } \\
\text { following sepsis }\end{array}$ & $\begin{array}{l}\text { Schimke et al. } \\
2013\end{array}$ \\
\hline 6 & $6 \mathrm{yr}$ & $\begin{array}{l}\text { RIC (TBI, Flu, Mel, Cy, } \\
\text { ATG), MMUD, NA }\end{array}$ & $211 d$ & Complete chimerism $(27 \mathrm{~d})$ & $\begin{array}{l}\text { (1) AGvHD; (2) anemia, } \\
\text { thrombocytopenia (180 d) and } \\
\text { cerebellar hemorrhage; (3) Died }\end{array}$ & $\begin{array}{l}\text { Yoshioka et al. } \\
2013\end{array}$ \\
\hline 7 & $2.4 \mathrm{yr}$ & NA, MUD, NA & $3 \mathrm{mo}$ & NA & $\begin{array}{l}\text { (1) Rapid neurologic deterioration, } \\
\text { severe progressive cerebral } \\
\text { atrophy; (2) Died }\end{array}$ & $\begin{array}{l}\text { Janssen et al. } \\
\text { 2004; Wu et al. } \\
2010\end{array}$ \\
\hline
\end{tabular}

Note: HSCT, hematopoietic stem cell transplantation; NA, not available; MAC, myeloablative conditioning; RIC, reduced intensity conditioning; Bu, busulfan; Cy, cyclophosphamide; Flu, fludarabine; Mel, melphalan; Treo, Treosulphan; ATG, antithymocyte globulin; Alem, alemtuzumab; CB, cord blood; BM, bone marrow; PBSC, peripheral blood stem cells; MSD, matched sibling donor; MMRD, mismatched related donor;

MUD, matched unrelated donor; MMUD, mismatched unrelated donor; AGvHD, acute graft versus host disease; CGvHD, chronic graft versus host disease; FTT, failure to thrive. 
IKK complex, hindering the phosphorylation of IкB. Mutations affect the innate and adaptive immunity, without clear EDA features (Pannicke et al. 2013; Mousallem et al. 2014).

Transplant for $I K B K B$ mutations has been reported in 7 patients of Northern Cree and Qatari ancestry (Pannicke et al. 2013; Mousallem et al. 2014). Transplanted patients presented in the first 6 months of life with FTT, invasive Gram negative infections, recurrent sinopulmonary infections, oral candidiasis, and disseminated Bacillus Calmette-Guérin (BCG) infections following vaccination (Table 5). Immunologic abnormalities in these patients included low B-cell counts with poor B-cell proliferation responses. NK cell counts were low and their cytotoxicity was diminished. Total T-cell counts varied, but an increased ratio of naive CD45RA to memory CD45RO was found in all patients, with low $\mathrm{TCR} \gamma / \delta$ and almost absent FoxP $3^{+}$regulatory T-cells. Responses of T-cells to mitogens and CD3 stimulations were greatly diminished or absent.

HSCT were performed in the 1st year of life (Table 6). Only 1 patient received RIC, while other 6 patients received MAC. MUD were used in 3 patients. Only 3 patients survived, with the longest follow-up being only 24 months, hence assessment of potential benefits of HSCT for this condition, and management recommendation, are premature.

\section{CARD11-BCL10-MALT1 complex immunodeficiency}

The CBM signalosome complex is essential in relaying cell-surface receptor activation signal, linking it to NFKB activation in the canonical pathway. Autosomal recessive mutations in this complex have emerged in recent years as causing immunodeficiency without EDA (Turvey et al. 2014).

Although mutations in all $3 \mathrm{CBM}$ signalosome proteins have been described, HSCT has only been reported between 2013 and 2016 in 6 patients with MALT1 and CARD11 mutations (Greil et al. 2013; Stepensky et al. 2013; Punwani et al. 2015; Charbit-Henrion et al. 2016; Rozmus et al. 2016). A summary of patient characteristics can be found in Table 7. Patients presented between 2 weeks and 9 months of age, with chronic diarrhea, significant dermatitis, and FTT. Infections included recurrent bacterial, viral and fungal sinopulmonary and skin infections, as well as opportunistic infections with PJP and CMV. Initial immunologic evaluation in the transplanted patients revealed eosinophilia and elevated IgE in patients with MALT1 deficiency. Predominantly naïve or transitional B-cell phenotypes were found in 5 patients, with hypo- or agammaglobulinemia in 3 patients. Patients T-cells typically demonstrated diminished response to lectin mitogens and (or) CD3 stimulation. T-regulatory cells were commonly reduced or absent. HSCT were performed at ages 18 months to 16 years (Table 8). MUD and misMUD were used in 4 patients while 2 received MRD from siblings. RIC was performed in all but 1 patient, for whom conditioning was not described. Successful engraftment with full donor chimerism was reported in 2 cases. Two patients continued to have moderate T-cell lymphopenia, and 2 more patients required stem cell boosts and (or) lymphocyte infusions due to slow T-cell recovery. All patients survived and are reported to be clinically well, however, the follow-up (1 year or less) prevents clear appreciation of HSCT for this condition.

\section{NIK immunodeficiency}

Biallelic mutations in the MAP3K14 gene result in loss-of-function of NIK, preventing the phosphorylation and subsequent activation of the IKK $\alpha$ complex in the non-canonical pathway. Recently, 2 members of a large consanguineous family of Turkish descent were identified with homozygous mutations in NIK (Willmann et al. 2014). A summary of patient characteristics can be found in Table 9. The patients' ages at time of presentation were not reported. One patient suffered from chronic diarrhea and cholestasis. Both patients suffered from severe viral and bacterial infections, as well as opportunistic infections with CMV and Cryptosporidium. BCG hepatitis following vaccine was diagnosed in 1 patient. Both patients had low B-cell counts with impaired proliferations. Low IgG and IgA were seen in both patients with normal to high IgM. T-cell counts were high with normal CD45RA to CD45RO ratio, but $\mathrm{T}$-cell response to recall antigens were low. NK count and cytotoxicity were reduced.

One patient, transplanted at 3 years of age without conditioning, failed to engraft and died after a repeated unconditioned HSCT (Table 10). The other patient received RIC HSCT at 9 years of age and is reported to be clinically well, however no additional details are 
Table 5: Characteristics of patients prior to transplantation for IKBKB/IKK2 mutations.

\begin{tabular}{|c|c|c|c|c|c|}
\hline Patient \# & Mutation & $\begin{array}{l}\text { Age at } \\
\text { presentation }\end{array}$ & $\begin{array}{l}\text { Clinical manifestations and } \\
\text { pathogens }\end{array}$ & Immune abnormalities & Report \\
\hline 1 & R286X & Early infancy & Candida, BCG & $\begin{array}{l}\text { (1) Reduced B-cells and memory B-cells; (2) Reduced NK cells; } \\
\text { (3) Increased CD45RA T-cells; (4) Hypogam, low IgA, IgM; } \\
\text { (5) Absent T-cell responses }\end{array}$ & $\begin{array}{l}\text { Mousallem et al. } \\
2014 \text { Patient } 1\end{array}$ \\
\hline 2 & $\mathrm{R} 286 \mathrm{X}$ & NA & $\begin{array}{l}\text { FTT, pneumonias, otitis, urinary } \\
\text { tract infections, Rotavirus, } \\
\text { Gram (-), Candida, BCG }\end{array}$ & $\begin{array}{l}\text { (1) Reduced B-cell; (2) Reduced NK cell; (3) Increased CD45RA } \\
\text { T-cells; (4) Low TCR } \gamma / \delta ;(5) \text { Hypogam, low IgA, IgM; } \\
\text { (6) Decreased/absent T-cell responses }\end{array}$ & $\begin{array}{l}\text { Mousallem et al. } \\
2014 \text { Patient } 2\end{array}$ \\
\hline 3 & $\mathrm{R} 286 \mathrm{X}$ & $1 \mathrm{wk}$ & FTT, recurrent fevers, Candida & $\begin{array}{l}\text { (1) Reduced B-cell and memory B-cells; (2) Reduced NK cells; } \\
\text { (3) Increased CD45RA T-cells; (4) low IgA and IgM; } \\
\text { (5) Reduced/absent T-cell responses }\end{array}$ & $\begin{array}{l}\text { Mousallem et al. } \\
2014 \text { Patient } 3\end{array}$ \\
\hline 4 & $\mathrm{R} 286 \mathrm{X}$ & $\begin{array}{l}\text { "First few months } \\
\text { of life" }\end{array}$ & $\begin{array}{l}\text { Klebsiella pneumonia, CMV, } \\
\text { Candida }\end{array}$ & $\begin{array}{l}\text { (1) Increased CD45RA T-cells; (2) Reduced TCR } \gamma / \delta \text {; } \\
\text { (3) Hypogam, low IgA, IgM; (4) Reduced/absent T-cell } \\
\text { responses }\end{array}$ & $\begin{array}{l}\text { Mousallem et al. } \\
2014 \text { Patient } 4\end{array}$ \\
\hline 5 & $\begin{array}{l}\text { c. } 1292 \text { dupG } \\
\text { in exon } 13\end{array}$ & $1 \mathrm{mo}$ & $\begin{array}{l}\text { Feeding difficulties, septicemia, } \\
\text { pneumonia, Candida, E. coli, } \\
\text { viruses }\end{array}$ & $\begin{array}{l}\text { (1) Increased naïve B-cells; (2) Absent B-cell responses; } \\
\text { (3) Absent TCR } / \delta \text {; (4) reduced Treg; (5) Increased CD45RA } \\
\text { T-cells; (6) Reduced NK activity; (7) Hypogam, low IgA, IgM; } \\
\text { (8) Reduced/absent T-cell responses }\end{array}$ & $\begin{array}{l}\text { Pannicke et al. } 2013 \\
\text { Patient } 1\end{array}$ \\
\hline 6 & $\begin{array}{l}\text { c. } 1292 \text { dupG } \\
\text { in exon } 13\end{array}$ & $5 \mathrm{mo}$ & $\begin{array}{l}\text { Chronic diarrhea, FTT, } \\
\text { pneumonia, Candida, virus }\end{array}$ & $\begin{array}{l}\text { (1) Increased naïve B-cells; (2) Absent B-cell responses; (3) Low } \\
\text { NK cells; (4) Absent TCR } / \delta \text {; (5) Reduced Treg; (6) Increased } \\
\text { CD45RA T-cells; (7) Reduced NK activity; (8) Absent T-cell } \\
\text { responses }\end{array}$ & $\begin{array}{l}\text { Pannicke et al. } 2013 \\
\text { Patient } 2\end{array}$ \\
\hline 7 & $\begin{array}{l}\text { c. } 1292 \text { dupG } \\
\text { in exon } 13\end{array}$ & $3 \mathrm{mo}$ & Candida, Gram (-) & $\begin{array}{l}\text { (1) Increased naïve B-cells; (2) Absent B-cell responses; } \\
\text { (3) Reduced NK and CD4 T-cells; (4) Absent TCR } / \delta \text {; } \\
\text { (5) Reduced Treg; (6) Increased CD45RA T-cells; } \\
\text { (7) Reduced NK activity; (8) Reduced/absent T-cell responses }\end{array}$ & $\begin{array}{l}\text { Pannicke et al. } 2013 \\
\text { Patient } 3\end{array}$ \\
\hline
\end{tabular}

Note: NA, not available; FTT, failure to thrive; Hypogam, hypogammaglobulinemia 


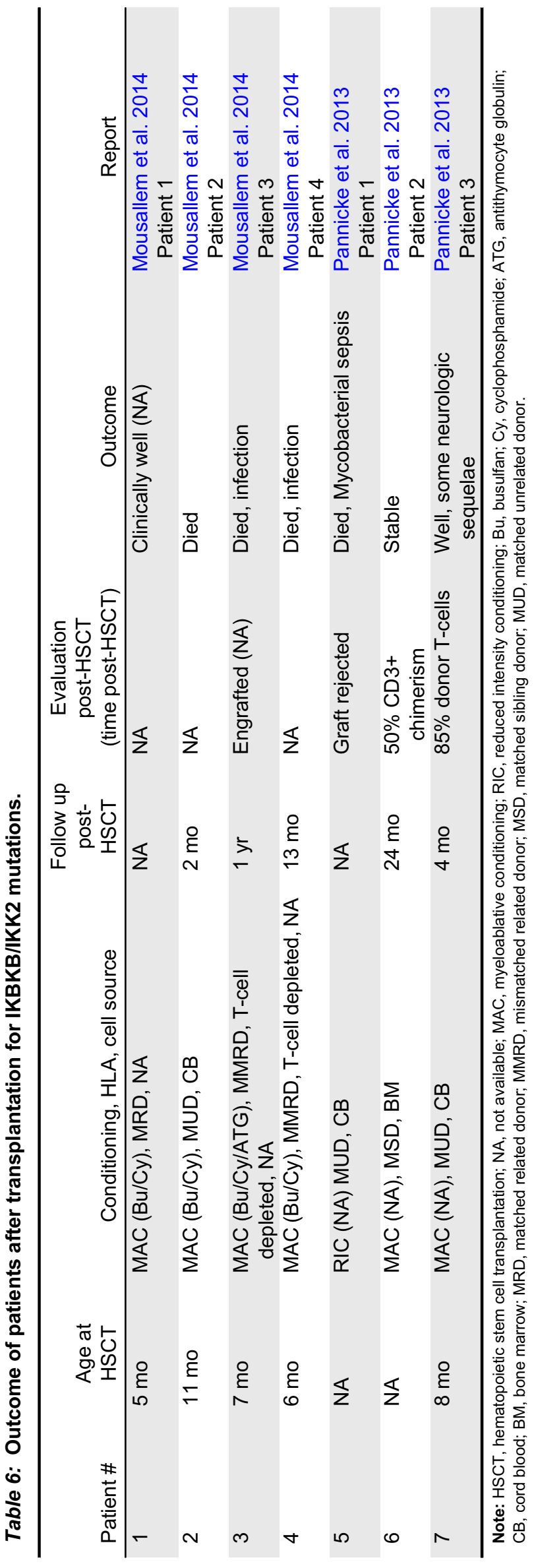

provided. Hence currently the role of HSCT for NIK deficiency cannot be determined.

\section{Discussion}

Mutations affecting the NFKB pathway represent a growing group of primary immune deficiencies, which range in their clinical manifestations and infectious susceptibility. Many patients receive supportive care to prevent and treat infections, as well as immune suppressive medications for the immune dysregulation. Yet, in recent years HSCT is being investigated as a potential cure, especially for those with more severe phenotypes or ominous family history. Among the 35 patients described here, 23 patients (65.7\%) are reported to be alive at the time publication, yet while it seems that survival is favorable in patients with XL-EDA-ID and CBM complex defects, patients with AD-EDA-ID and possibly $I K B K B$ defects fare worse following HSCT. The disappointing survival in patients with some of the $\mathrm{NF \kappa B}$ defects might be related to delays in diagnosis of patients, allowing development of infections that negatively affect outcome. Indeed, among patients with severe combined immune deficiency, transplantation beyond 3.5 months of age and active infection at the time of HSCT is associated with only $50 \%$ survival at 5 years, while transplanting prior to the development of infections or after they are controlled significantly improved survival (Pai et al. 2014). Current newborn screening programs for profound $\mathrm{T}$ cell deficiencies often do not identify patients with NFkB defects. Therefore, increased awareness of health care providers to the possibility of such defects and early consideration of HSCT are required, together with optimal prevention and treatment of infections.

Details about conditioning were available for 30 patients, with half receiving MAC and the remainder receiving RIC. Survival was similar with 10 of 15 patients (66.6\%) surviving after MAC compared to 9 of 15 (60\%) surviving after RIC. However, follow-up after RIC was much shorter (often less than 2 years) compared to several patients who received MAC (2-15 years). Moreover, in some defects, engraftment and complete immune reconstitution might be more difficult to achieve, such as T-cells and B-cells in CBM and NFKBIA defects, respectively. Whether the persistently low number of switched-memory B-cells is also related to the developmental abnormalities of secondary lymphoid organs caused by the I $\mathrm{B} \alpha$ defect remains to 
Table 7: Characteristics of patients prior to transplantation for CBM complex mutations.

\begin{tabular}{|c|c|c|c|c|c|}
\hline Patient \# & Mutation & $\begin{array}{c}\text { Age at } \\
\text { presentation }\end{array}$ & $\begin{array}{l}\text { Clinical manifestations } \\
\text { and pathogens }\end{array}$ & Immune abnormalities & Report \\
\hline 1 & MALT1 c.550G >T & $1 \mathrm{mo}$ & $\begin{array}{l}\text { IPEX-like syndrome, bacterial, } \\
\text { viral and fungal }\end{array}$ & \multicolumn{2}{|c|}{$\begin{array}{l}\text { (1) Eosinophilia; (2) Reduced CD21 B-cells; (3) Reduced Treg;Charbit-Henrion et al. } \\
\text { (4) High IgE; (5) Reduced T-cell responses }\end{array}$} \\
\hline 2 & MALT1 c.550G >T & NA & Dermatitis, repeated infections & \multicolumn{2}{|c|}{$\begin{array}{l}\text { (1) Eosinophilia; (2) Reduced CD21 B-cells; (3) Reduced Treg;Charbit-Henrion et al. } \\
\text { (4) High IgE; (5) Reduced T-cell responses } 2016 \text { Patient } 2\end{array}$} \\
\hline 3 & CARD11 Q945* & $6 \mathrm{mo}$ & PJP & $\begin{array}{l}\text { (1) Low NK cell; (2) Increased CD45RA T-cells; } \\
\text { (3) Increased CD27-B-cells; (4) Absent Treg; } \\
\text { (5) Agammaglobulinemia; (6) Reduced T-cell responses; (7) } \\
\text { Reduced responses to TLR }\end{array}$ & Greil et al. 2013 \\
\hline 4 & $\begin{array}{l}\text { MALT1 c. } 1019- \\
2 A>G ; \text { p.Y353fs*18 }\end{array}$ & $1 \mathrm{mo}$ & $\begin{array}{l}\text { Bloody diarrhea, } \\
\text { desquamating erythema, } \\
\text { stomatitis, FTT, otitis, thrush, } \\
\text { CMV }\end{array}$ & $\begin{array}{l}\text { (1) Lymphocytosis, eosinophilia; (2) Increased CD45RA } \\
\text { T-cells; (3) Reduced Treg; (4) Hypogam, low IgM; } \\
\text { (5) Reduced antibody response to vaccines; } \\
\text { (6) Reduced T-cell responses }\end{array}$ & Punwani et al. 2015 \\
\hline 5 & MALT1 c. $1739 \mathrm{G}>\mathrm{C}$ & 2 wk & $\begin{array}{l}\text { FTT, fractures, inflammatory } \\
\text { bowel disease, dermatitis, } \\
\text { viral and bacterial } \\
\text { pneumonias, MRSA, HSV, } \\
\text { VZV; cheilitis, gingivitis }\end{array}$ & $\begin{array}{l}\text { (1) Reduced B-cells; (2) High IgE; (3) Reduced T-cell } \\
\text { responses }\end{array}$ & Rozmus et al. 2016 \\
\hline 6 & $\begin{array}{l}\text { CARD11 deletion of } \\
\text { exon } 21\end{array}$ & $9 \mathrm{mo}$ & PJP & $\begin{array}{l}\text { (1) Lymphocytosis; }(2) \text { Increased transitional B-cells, } \\
\text { reduced class-switched memory cells; (3) Reduced } \\
\text { Treg }\left(C D 4^{+} C D 25^{+} C D 127^{-}\right) \text {; (4) Reduced differentiated CD8 } \\
\text { cells; (5) hypogam, low IgA, IgM }\end{array}$ & $\begin{array}{l}\text { Stepensky et al. } \\
2013\end{array}$ \\
\hline
\end{tabular}

Note: NA, not available; FTT, failure to thrive; Hypogam, hypogammaglobulinemia. 
Table 8: Outcome of patients after transplantation for CBM complex mutations.

\begin{tabular}{|c|c|c|c|c|c|c|}
\hline Patient \# & $\begin{array}{l}\text { Age at } \\
\text { HSCT }\end{array}$ & $\begin{array}{l}\text { Conditioning, HLA, } \\
\text { cell source }\end{array}$ & $\begin{array}{l}\text { Follow up } \\
\text { post-HSCT }\end{array}$ & Evaluation post-HSCT (time post-HSCT) & Outcome & Report \\
\hline 1 & $7 \mathrm{yr}$ & $\begin{array}{l}\text { RIC (Flu/Bu/Alem), } \\
\text { MUD, PBSC }\end{array}$ & $12 \mathrm{mo}$ & $\begin{array}{l}\text { (1) Complete (300 d); (2) T-cell lymphopenia; } \\
\text { (3) T-cell responses normalized; (4) Treg } \\
\text { increased }\end{array}$ & $\begin{array}{l}\text { (1) Clinically well; }(2) \mathrm{CMV} \\
\text { reactivation resolved }\end{array}$ & $\begin{array}{l}\text { Charbit-Henrion et al. } \\
2016 \text { Patient } 1\end{array}$ \\
\hline 2 & $4 \mathrm{yr}$ & $\begin{array}{l}\text { RIC (Flu/Bu/Alem), } \\
\text { MUD, PBSC }\end{array}$ & $12 \mathrm{mo}$ & $\begin{array}{l}\text { (1) } 75 \% \text { chimerism: }(250 \mathrm{~d}) \text {; (2) T-cell } \\
\text { lymphopenia; (3) T-cell responses improved; } \\
\text { (4) Treg improved }\end{array}$ & $\begin{array}{l}\text { (1) Clinically well, improved } \\
\text { growth; (2) CMV reactivation } \\
\text { resolved }\end{array}$ & $\begin{array}{l}\text { Charbit-Henrion et al. } \\
2016 \text { Patient } 2\end{array}$ \\
\hline 3 & $9 \mathrm{mo}$ & $\begin{array}{l}\text { RIC (Flu/Treo/Alem, } \\
\text { MUD, PBSC }\end{array}$ & $12 \mathrm{mo}$ & $\begin{array}{l}\text { (1) Decreasing chimerism, requiring stem cell } \\
\text { boosts and donor lymphocyte infusions }\end{array}$ & Clinically well & Greil et al. 2013 \\
\hline 4 & $18 \mathrm{mo}$ & $\begin{array}{l}\text { RIC (Cy/Mel/ATG) } \\
\text { MMUD, PBSC }\end{array}$ & $12 \mathrm{mo}$ & $\begin{array}{l}\text { (1) } 16.6 \% \text { donor T-cells, } 11.2 \% \mathrm{PBL} \text {; (2) T cell } \\
\text { functional ( } 5 \mathrm{mo}) \text {; (3) CMV pulsed donor } \\
\text { T-cells infusion (12 mo); (4) IVIg }\end{array}$ & $\begin{array}{l}\text { (1) Clinically well; (2) Rash, } \\
\text { intractable diarrhea, and CMV } \\
\text { resolved }\end{array}$ & Punwani et al. 2015 \\
\hline 5 & $16 \mathrm{yr}$ & $\begin{array}{l}\text { RIC (Flu/Mel/Alem), } \\
\text { MSD, NA }\end{array}$ & $1 \mathrm{yr}$ & $\begin{array}{l}\text { (1) }>95 \% \text { donor chimerism (1 yr); } \\
\text { (2) Normalized B-cell counts and maturation }\end{array}$ & $\begin{array}{l}\text { (1) Improved growth, } \\
\text { dermatitis, and inflammatory } \\
\text { bowel disease resolved; } \\
\text { (2) Viral and bacterial } \\
\text { infections resolved }\end{array}$ & Rozmus et al. 2016 \\
\hline 6 & NA & $N A, M S D, N A$ & $5 \mathrm{mo}$ & (1) Complete chimerism; (2) Normal IgG & Clinically well & $\begin{array}{l}\text { Stepensky et al. } \\
2013\end{array}$ \\
\hline
\end{tabular}

Note: HSCT, hematopoietic stem cell transplantation; NA, not available; MAC, myeloablative conditioning; RIC, reduced intensity conditioning; Bu, busulfan; Cy, cyclophosphamide; Flu, fludarabine; Mel, melphalan;

ATG, antithymocyte globulin; Alem, alemtuzumab; PBSC, peripheral blood stem cells; MSD, matched sibling donor; MUD, matched unrelated donor; MMUD, mismatched unrelated donor

Table 9: Characteristic of patients prior to transplantations for MAP3K14/NIK mutations.

\begin{tabular}{|c|c|c|c|c|c|}
\hline Patient \# & Mutation & $\begin{array}{c}\text { Age at } \\
\text { presentation }\end{array}$ & $\begin{array}{l}\text { Clinical manifestations and } \\
\text { pathogens }\end{array}$ & Immune abnormalities & Report \\
\hline 1 & c.C1694G & NA & $\begin{array}{l}\text { Viral - including CMV and } \\
\text { bacterial infections, BCG } \\
\text { cryptosporidium }\end{array}$ & $\begin{array}{l}\text { (1) Low B and switched memory B-cells; (2) Reduced B-cell; } \\
\text { (3) Low NK cells; (4) Hypogam and low IgA, high IgM; } \\
\text { (5) Reduced NK activity; (6) Reduced T-cell responses }\end{array}$ & $\begin{array}{l}\text { Willmann et al. } 2014 \\
\text { Patient } 1\end{array}$ \\
\hline 2 & c.C1694G & NA & $\begin{array}{l}\text { Chronic diarrhea, cholestasis } \\
\text { pneumonias, Candida, } \\
\text { CMV, cryptosporidium }\end{array}$ & $\begin{array}{l}\text { (1) Low B and switched memory B-cells; (2) Reduced B-cells; } \\
\text { (3) Low NK cells; (4) Hypogam and low IgA, high IgM; } \\
\text { (5) Reduced NK activity; (6) Reduced T-cell responses }\end{array}$ & $\begin{array}{l}\text { Willmann et al. } 2014 \\
\text { Patient } 2\end{array}$ \\
\hline
\end{tabular}

Note: NA, not available; Hypogam, hypogammaglobulinemia. 
be determined (Scarselli et al. 2015). Hence, the optimal conditioning for patients with NFKB defects undergoing HSCT is still not clear, particularly when considering the multiple cells of the immune system that are dependent on NFKB pathway.

While HSCT can correct the immune abnormalities associated with NFKB defects, particularly if full donor chimerism is achieved, patients might still be susceptible to non-immune morbidities, possibly because of the role of NFKB in diverse biological processes. Indeed, only $14(40 \%)$ of the transplanted patients were reported to be clinically well. Moreover, because follow-up in many of these patients has been short, additional morbidity may still be revealed. Some of the complications identified hitherto include liver toxicity, inflammatory bowel disease and neurological abnormalities. The liver toxicity was seen already in 3 patients who received MAC, leading Klemann et al. to propose that NEMO mutations predispose to hepatic complications (Klemann et al. 2016). Liver injury and hepatic veno-occlusive disease are uncommon after HSCT for most inherited immune defects, yet it has been reported in patients undergoing HSCT for hemophagocytic lymphohistiocytosis (Ouachée-Chardin et al. 2006) and ataxia telangiectasia (Beier et al. 2016), possibly due to subtle pre-existing liver inflammation or increased sensitivity of liver cells to chemotherapy. Whether these factors also contribute to the hepatic abnormalities following HSCT for NFKB pathway defects is not known, yet close monitoring of liver enzymes and early intervention might be beneficial in affected patients. An intriguing concept is the development of inflammatory bowel disease following transplant in patients with NEMO mutations. Significant bowel inflammation may develop in up to $20 \%$ of NEMO-deficient patients. Thus it is difficult to draw conclusions from the appearance of bowel pathology in 4 of 10 transplanted NEMO-deficient patients, despite the occurrence of similar complication after HSCT in a murine model of NEMO defect (Nenci et al. 2007). Whether translocation of enteric bacteria across impaired intestinal barrier of NEMO-deficient mice, combined with an aggressive immune response, contributed to the GI damage is still debatable (Nenci et al. 2007).

\section{Conclusion}

In conclusion, HSCT can correct the immune defects associated with mutations in the NFKB pathway, however such procedures are still associated with substantial 
morbidity and mortality. Moreover, non-immune abnormalities may persist or develop after HSCT, hence the benefits from HSCT should be carefully considered in every patient. Earlier identification and transplantation of affected patients as well as better understanding of the pathogenesis and complications of the different NFאB mutations might improve outcome HSCT for specific patient populations.

\section{Funding}

This work was supported in part by the Donald and Audrey Campbell Chair for Immunology research to EG.

\section{REFERENCES}

Abbott, J.K., Quinones, R.R., de la Morena, M.T., and Gelfand, E.W. 2014. Successful hematopoietic cell transplantation in patients with unique NF- $\kappa B$ essential modulator (NEMO) mutations. Bone Marrow Transplant. 49(11):1446-1447. PMID: 25068423. doi: 10.1038/bmt.2014.157.

Beier, R., Sykora, K.W., Woessmann, W., MaeckerKolhoff, B., Sauer, M., Kreipe, H.H., Dörk-Bousset, T., Kratz, C., and Lauten, M.2016. Allogeneicmatched sibling stem cell transplantation in a 13-year-old boy with ataxia telangiectasia and EBVpositive non-Hodgkin lymphoma. Bone Marrow Transplant. 51(9):1271-1274. PMID: 27159176. doi: 10.1038/bmt.2016.93.

Carlberg, V.M., Lofgren, S.M., Mann, J.A., Austin, J.P., Nolt, D., Shereck, E.B., Davila-Saldana, B., Zonana, J., and Krol, A.L. 2014. Hypohidrotic ectodermal dysplasia, osteopetrosis, lymphedema, and immunodeficiency in an infant with multiple opportunistic infections. Pediatr. Dermatol. 31(6):716-721. PMID: 23405946. doi: 10.1111/pde.12103.

Charbit-Henrion, F., Jeverica, A.K., Bègue, B., Markelj, G., Parlato, M., Avčin, S.L., Callebaut, I., Bras, M., Parisot, M., Jazbec, J., Homan, M., Ihan, A., RieuxLaucat, F., Stolzenberg, M.C., Ruemmele, F.M., Avčin, T., and Cerf-Bensussan, N. 2016. Deficiency in mucosa associated lymphoid tissue lymphoma translocation 1 (MALT1): A novel cause of Ipex-Like syndrome. J. Pediatr. Gastroenterol. Nutr. 64(3): 378-384. PMID: 27253662. doi: 10.1097/MPG. 0000000000001262.

Courtois, G. 2005. The NF- $\mathrm{BB}$ signaling pathway in human genetic diseases. Cell. Mol. Life Sci. 62(15): 1682-1691. PMID: 15924263. doi: 10.1007/ s00018-005-5031-5.
Courtois, G., Smahi, A., Reichenbach, J., Döffinger, R., Cancrini, C., Bonnet, M., Puel, A., Chable-Bessia, C., Yamaoka, S., Feinberg, J., Dupuis-Girod, S., Bodemer, C., Livadiotti, S., Novelli, F., Rossi, P., Fischer, A., Israël, A., Munnich, A., Le Deist, F., and Casanova, J.L. 2003. A hypermorphic IкB $\alpha$ mutation is associated with autosomal dominant anhidrotic ectodermal dysplasia and $\mathrm{T}$ cell immunodeficiency. J. Clin. Invest. 112(7):1108-1115. PMID: 14523047. doi: 10.1172/JCI18714.

Devora, G.A., Sun, L., Chen, Z., van Oers, N.S., Hanson, E.P., Orange, J.S., and de la Morena, M.T. 2010. A novel missense mutation in the nuclear factor $-\kappa B$ essential modulator (NEMO) gene resulting in impaired activation of the NF- $\kappa B$ pathway and a unique clinical phenotype presenting as MRSA subdural empyema. J. Clin. Immunol. 30(6):881-885. doi: 10.1007/ s10875-010-9445-y.

Dupuis-Girod, S., Cancrini, C., Le Deist, F., Palma, P., Bodemer, C., Puel, A., Livadiotti, S., Picard, C., Bossuyt, X., Rossi, P., Fischer, A., and Casanova, J.L. 2006. Successful allogeneic hemopoietic stem cell transplantation in a child who had anhidrotic ectodermal dysplasia with immunodeficiency. Pediatrics. 118(1):e205-e211. PMID: 16769798. doi: 10.1542/ peds.2005-2661.

Dupuis-Girod, S., Corradini, N., Hadj-Rabia, S., Fournet, J.C., Faivre, L., Le Deist, F., Durand, P., Döffinger, R., Smahi, A., Israel, A., Courtois, G., Brousse, N., Blanche, S., Munnich, A., Fischer, A., Casanova, J.L., and Bodemer, C. 2002. Osteopetrosis, lymphedema, anhidrotic ectodermal dysplasia, and immunodeficiency in a boy and incontinentia pigmenti in his mother. Pediatrics. 109(6):e97. PMID: 12042591. doi: 10.1542/peds.109.6.e97.

Fish, J.D., Duerst, R.E., Gelfand, E.W., Orange, J.S., and Bunin, N. 2009. Challenges in the use of allogeneic hematopoietic SCT for ectodermal dysplasia with immune deficiency. Bone Marrow Transplant. 43(3):217-221. PMID: 18794870. doi: 10.1038/ bmt.2008.308.

Gilmore, T.D. 2006. Introduction to NF-кB: Players, pathways, perspectives. Oncogene. 25(51):6680-6684. PMID: 17072321. doi: 10.1038/sj.onc.1209954.

Greil, J., Rausch, T., Giese, T., Bandapalli, O.R., Daniel, V., Bekeredjian-Ding, I., Stütz, A.M., Drees, C., Roth, S., Ruland, J., Korbel, J.O., and Kulozik, A.E. 2013. Whole-exome sequencing links caspase recruitment domain 11 (CARD11) inactivation to severe combined immunodeficiency. J. Allergy Clin. Immunol. 
131(5):1376-1383.e3. PMID: 23561803. doi: 10.1016/j. jaci.2013.02.012.

Imamura, M., Kawai, T., Okada, S., Izawa, K., Takachi, T., Iwabuchi, H., Yoshida, S., Hosokai, R., Kanegane, H., Yamamoto, T., Umezu, H., Nishikomori, R., Heike, T., Uchiyama, M., and Imai, C. 2011. Disseminated BCG infection mimicking metastatic nasopharyngeal carcinoma in an immunodeficient child with a novel hypomorphic NEMO mutation. J. Clin. Immunol. 31(5):802-810. PMID: 21755389. doi: 10.1007/ s10875-011-9568-9.

Janssen, R., van Wengen, A., Hoeve, M.A., ten Dam, M., van der Burg, M., van Dongen, J., van de Vosse, E., van Tol, M., Bredius, R., Ottenhoff, T.H., Weemaes, C., van Dissel, J.T., and Lankester, A. 2004. The same $\mathrm{I} \kappa \mathrm{B} \alpha$ mutation in two related individuals leads to completely different clinical syndromes. J. Exp. Med. 200(5):559-568. PMID: 15337789. doi: 10.1084/ jem.20040773.

Kawai, T., Nishikomori, R., Izawa, K., Murata, Y., Tanaka, N., Sakai, H., Saito, M., Yasumi, T., Takaoka, Y., Nakahata, T., Mizukami, T., Nunoi, H., Kiyohara, Y., Yoden, A., Murata, T., Sasaki, S., Ito, E., Akutagawa, H., Kawai, T., Imai, C., Okada, S., Kobayashi, M., and Heike, T. 2012. Frequent somatic mosaicism of NEMO in $\mathrm{T}$ cells of patients with $\mathrm{X}$-linked anhidrotic ectodermal dysplasia with immunodeficiency. Blood. 119(23):5458-5466. PMID: 22517901. doi: 10.1182/blood-2011-05-354167.

Klemann, C., Pannicke, U., Morris-Rosendahl, D.J., Vlantis, K., Rizzi, M., Uhlig, H., Vraetz, T., Speckmann, C., Strahm, B., Pasparakis, M., Schwarz, K., Ehl, S., and Rohr, J.C. 2016. Transplantation from a symptomatic carrier sister restores host defenses but does not prevent colitis in NEMO deficiency. Clin. Immunol. 164:52-56. PMID: 26812624. doi: 10.1016/j.clim.2016.01.010.

Lopez-Granados, E., Keenan, J.E., Kinney, M.C., Leo, H., Jain, N., Ma, C.A., Quinones, R., Gelfand, E.W., and Jain, A. 2008. A novel mutation in NFKBIA/IKBA results in a degradation-resistant $\mathrm{N}$-truncated protein and is associated with ectodermal dysplasia with immunodeficiency. Hum. Mutat. 29(6):861-868. PMID: 18412279. doi: 10.1002/humu.20740.

Mancini, A.J., Lawley, L.P., and Uzel, G. 2008. X-linked ectodermal dysplasia with immunodeficiency caused by NEMO mutation: Early recognition and diagnosis. Arch. Dermatol. 144(3):342-346. PMID: 18347290. doi: 10.1001/archderm.144.3.342.

Martinez-Pomar, N., Munoz-Saa, I., Heine-Suner, D., Martin, A., Smahi, A., and Matamoros, N. 2005. A new mutation in exon 7 of NEMO gene: Late skewed $\mathrm{X}$-chromosome inactivation in an incontinentia pigmenti female patient with immunodeficiency. Hum. Genet. 118(3-4):458-465. PMID: 16228229. doi: 10.1007/s00439-005-0068-y.

Minakawa, S., Takeda, H., Nakano, H., Tono, C., Takahashi, Y., Sasaki, S., Terui, K., Ito, E., and Sawamura, D. 2009. Successful umbilical cord blood transplantation for intractable eczematous eruption in hypohidrotic ectodermal dysplasia with immunodeficiency. Clin. Exp. Dermatol. 34(7):e441-e442. PMID: 19663838. doi: 10.1111/j.1365-2230.2009. 03473.x.

Mousallem, T., Yang, J., Urban, T.J., Wang, H., Adeli, M., Parrott, R.E., Roberts, J.L., Goldstein, D.B., Buckley, R.H., and Zhong, X.P. 2014. A nonsense mutation in IKBKB causes combined immunodeficiency. Blood. 124(13):2046-2050. PMID: 25139357. doi: 10.1182/blood-2014-04571265.

Nenci, A., Becker, C., Wullaert, A., Gareus, R., van Loo, G., Danese, S., Huth, M., Nikolaev, A., Neufert, C., Madison, B., Gumucio, D., Neurath, M.F., and Pasparakis, M. 2007. Epithelial NEMO links innate immunity to chronic intestinal inflammation. Nature. 446(7135):557-561. PMID: 17361131. doi: 10.1038/nature05698.

Orange, J.S., and Geha, R.S. 2003. Finding NEMO: Genetic disorders of NF- $\kappa \mathrm{B}$ activation. J. Clin. Invest. 112(7):983-985. PMID: 14523034. doi: 10.1172/JCI19960.

Orange, J.S., Jain, A., Ballas, Z.K., Schneider, L.C., Geha, R.S., and Bonilla, F.A. 2004. The presentation and natural history of immunodeficiency caused by nuclear factor $\kappa \mathrm{B}$ essential modulator mutation. J. Allergy Clin. Immunol. 113(4):725-733. PMID: 15100680. doi: 10.1016/j.jaci.2004.01.762.

Ouachée-Chardin, M., Elie, C., de Saint Basile, G., Le Deist, F., Mahlaoui, N., Picard, C., Neven, B., Casanova, J.L., Tardieu, M., Cavazzana-Calvo, M., and Blanche, S. 2006. Hematopoietic stem cell transplantation in hemophagocytic lymphohistiocytosis: A single-center report of 48 patients. Pediatrics. 117(4):e743-e750. PMID: 16549504. doi: 10.1542/ peds.2005-1789.

Pai, S.Y., Levy, O., Jabara, H.H., Glickman, J.N., StolerBarak, L., Sachs, J., Nurko, S., Orange, J.S., and Geha, R.S. 2008. Allogeneic transplantation successfully corrects immune defects, but not susceptibility to colitis, in a patient with nuclear factor- $\kappa \mathrm{B}$ essential modulator deficiency. J. Allergy Clin. Immunol. 122(6): 
1113-1118.e1. PMID: 18851875. doi: 10.1016/j. jaci.2008.08.026.

Pai, S.Y., Logan, B.R., Griffith, L.M., Buckley, R.H., Parrott, R.E., Dvorak, C.C., Kapoor, N., Hanson, I.C., Filipovich, A.H., Jyonouchi, S., and Sullivan, K.E. 2014. Transplantation outcomes for severe combined immunodeficiency, 2000-2009. N. Engl. J. Med. 371(5):434-446. PMID: 25075835. doi: 10.1056/ NEJMoa1401177.

Pannicke, U., Baumann, B., Fuchs, S., Henneke, P., Rensing-Ehl, A., Rizzi, M., Janda, A., Hese, K., Schlesier, M., Holzmann, K., Borte, S., Laux, C., Rump, E.M., Rosenberg, A., Zelinski, T., Schrezenmeier, H., Wirth, T., Ehl, S., Schroeder, M.L., and Schwarz, K. 2013. Deficiency of innate and acquired immunity caused by an IKBKB mutation. N. Engl. J. Med. 369(26):2504-2514. PMID: 24369075. doi: 10.1056/NEJMoa1309199.

Permaul, P., Narla, A., Hornick, J.L., and Pai, S.Y. 2009. Allogeneic hematopoietic stem cell transplantation for X-linked ectodermal dysplasia and immunodeficiency: Case report and review of outcomes. Immunol. Res. 44(1-3):89-98. PMID: 19225723. doi: 10.1007/s12026-008-8085-2.

Punwani, D., Wang, H., Chan, A.Y., Cowan, M.J., Mallott, J., Sunderam, U., Mollenauer, M., Srinivasan, R., Brenner, S.E., Mulder, A., Claas, F.H., Weiss, A., and Puck, J.M. 2015. Combined immunodeficiency due to MALT1 mutations, treated by hematopoietic cell transplantation. J. Clin. Immunol. 35(2):135-146. PMID: 25627829. doi: 10.1007/ s10875-014-0125-1.

Rozmus, J., McDonald, R., Fung, S.Y., Del Bel, K.L., Roden, J., Senger, C., Schultz, K.R., McKinnon, M.L., Davis, J., and Turvey, S.E. 2016. Successful clinical treatment and functional immunological normalization of human MALT1 deficiency following hematopoietic stem cell transplantation. Clin. Immunol. 168:1-5. PMID: 27109639. doi: 10.1016/j.clim. 2016.04.011.

Salt, B.H., Niemela, J.E., Pandey, R., Hanson, E.P., Deering, R.P., Quinones, R., Jain, A., Orange, J.S., and Gelfand, E.W. 2008. IKBKG (nuclear factor- $\kappa$ B essential modulator) mutation can be associated with opportunistic infection without impairing Toll-like receptor function. J. Allergy Clin. Immunol. 121(4):976-982. PMID: 18179816. doi: 10.1016/j. jaci.2007.11.014.

Scarselli, A., Di Cesare, S., Capponi, C., Cascioli, S., Romiti, M.L., Di Matteo, G., Simonetti, A., Palma, P., Finocchi, A., Lucarelli, B., Pinto, R.M., Rana, I.,
Palumbo, G., Caniglia, M., Rossi, P., Carsetti, R., Cancrini, C., and Aiuti, A. 2015. Longitudinal evaluation of immune reconstitution and B-cell function after hematopoietic cell transplantation for primary immunodeficiency. J. Clin. Immunol. 35(4):373-383. PMID: 25875698. doi: 10.1007/s10875-015-0154-4.

Schimke, L.F., Rieber, N., Rylaarsdam, S., CabralMarques, O., Hubbard, N., Puel, A., Kallmann, L., Sombke, S.A., Notheis, G., Schwarz, H.P., Kammer, B., Hökfelt, T., Repp, R., Picard, C., Casanova, J.L., Belohradsky, B.H., Albert, M.H., Ochs, H.D., Renner, E.D., and Torgerson, T.R. 2013. A novel gain-of-function IKBA mutation underlies ectodermal dysplasia with immunodeficiency and polyendocrinopathy. J. Clin. Immunol. 33(6): 1088-1099. PMID: 23708964. doi: 10.1007/s10875013-9906-1.

Smahi, A., Courtois, G., Rabia, S.H., Döffinger, R., Bodemer, C., Munnich, A., Casanova, J.L., and Israël, A. 2002. The NF- $\kappa$ B signalling pathway in human diseases: From incontinentia pigmenti to ectodermal dysplasias and immune-deficiency syndromes. Hum. Mol. Genet. 11(20):2371-2375. PMID: 12351572. doi: 10.1093/hmg/11.20.2371.

Stepensky, P., Keller, B., Buchta, M., Kienzler, A.K., Elpeleg, O., Somech, R., Cohen, S., Shachar, I., Miosge, L.A., Schlesier, M., Fuchs, I., Enders, A., Eibel, H., Grimbacher, B., and Warnatz, K. 2013. Deficiency of caspase recruitment domain family, member 11 (CARD11), causes profound combined immunodeficiency in human subjects. J. Allergy Clin. Immunol. 131(2):477-485.e1. PMID: 23374270. doi: 10.1016/j.jaci.2012.11.050.

Tono, C., Takahashi, Y., Terui, K., Sasaki, S., Kamio, T., Tandai, S., Sato, T., Kudo, K., Toki, T., Tachibana, N., Yoshioka, T., Nakahata, T., Morio, T., Nishikomori, R., and Ito, E. 2007. Correction of immunodeficiency associated with NEMO mutation by umbilical cord blood transplantation using a reduced-intensity conditioning regimen. Bone Marrow Transplant. 39(12):801-804. PMID: 17417663. doi: 10.1038/sj. bmt.1705658.

Turvey, S.E., Durandy, A., Fischer, A., Fung, S.Y., Geha, R.S., Gewies, A., Giese, T., Greil, J., Keller, B., McKinnon, M.L., Neven, B., Rozmus, J., Ruland, J., Snow, A.L., Stepensky, P., and Warnatz, K. 2014. The CARD11-BCL10-MALT1 (CBM) signalosome complex: Stepping into the limelight of human primary immunodeficiency. J. Allergy Clin. Immunol. 134(2):276-284. PMID: 25087226. doi: 10.1016/j. jaci.2014.06.015. 
Willmann, K.L., Klaver, S., Doğu, F., Santos-Valente, E., Garncarz, W., Bilic, I., Mace, E., Salzer, E., Conde, C.D., Sic, H., Májek, P., Banerjee, P.P., Vladimer, G.I., Haskoloğlu, S., Bolkent, M.G., Küpesiz, A., CondinoNeto, A., Colinge, J., Superti-Furga, G., Pickl, W.F., van Zelm, M.C., Eibel, H., Orange, J.S., Ikincioğulları, A., and Boztuğ, K. 2014. Biallelic lossof-function mutation in NIK causes a primary immunodeficiency with multifaceted aberrant lymphoid immunity. Nat. Commun. 5:5360. PMID: 25406581. doi: 10.1038/ncomms6360.

Wu, S., Walenkamp, M.J., Lankester, A., Bidlingmaier, M., Wit, J.M., and De Luca, F. 2010. Growth hormone and insulin-like growth factor I insensitivity of fibroblasts isolated from a patient with an IкB $\alpha$ mutation. J. Clin. Endocrinol. Metab. 95(3):1220-1228. PMID: 20080849. doi: 10.1210/jc.2009-1662.

Yoshioka, T., Nishikomori, R., Hara, J., Okada, K., Hashii, Y., Okafuji, I., Nodomi, S., Kawai, T., Izawa, K., Ohnishi, H., Yasumi, T., Nakahata, T., and Heike, T. 2013. Autosomal dominant anhidrotic ectodermal dysplasia with immunodeficiency caused by a novel NFKBIA mutation, p. Ser36Tyr, presents with mild ectodermal dysplasia and non-infectious systemic inflammation. J. Clin. Immunol. 33(7): 1165-1174. PMID: 23864385. doi: 10.1007/ s10875-013-9924-z. 